\title{
APPLICATION OF PASSIVE METHODS OF ROBUST ESTIMATION: BAARDA'S AND POPE'S IN REAL ESTATE MARKET ANALYSIS
}

\author{
Beata Śpiewak, M.Sc. \\ Faculty of Mining Surveying and Environmental Engineering \\ AGH University of Science and Technology \\ e-mail: spiewak@agh.edu.pl
}

\begin{abstract}
The article presents the results of research into the appraisal of the usefulness and effectiveness of passive methods of robust estimation in real estate market analysis. Two methods are considered, i.e.: Baarda's and Pope's. The research is based on a database of flats sold in Kraków in 2015.

It has been proved that algorithms of robust estimation allow for eliminating outlying transactions from the collected database, causing the set of observations to become coherent and free of observations which might be fraught with gross error caused by the human factor.
\end{abstract}

Key words: robust estimation, real estate market analysis, residential properties, Baarda's method, Pope's method.

JEL Classification: C13,C51, R30, R39.

Citation: Śpiewak B., 2018, Application of Passive Methods of Robust Estimation: Baarda's and Pope's in Real Estate Market Analysis, Real Estate Management and Valuation, vol. 26, no. 1, pp. 05-15.

DOI: $10.2478 /$ remav-2018-0001

\section{Introduction}

Real estate market analysis is a process which leads to property valuation, thus collecting information about properties which are similar to the valuated property is crucial for determining market value. Information obtained from the property market without a predefined search key is said to be random, meaning that it may contain atypical observations. The article thus attempts to compile a dataset that is free of outlying observations. The statistical tool used was robust estimation, but only its two passive methods were discussed, i.e.: Baarda's and Pope's.

\section{Literature review on the application of robust estimation}

Datasets that are used to estimate the parameters of a statistical model often contain anomalous information about values of variables describing this information. This can be caused by the specificity of the examined phenomenon or by mistakes (TRZESIOK2014). Literature presents many methods of searching for atypical observations within analyzed datasets. One of them is robust estimation, which is used mainly in economic analyses (ORWAT 2006; DEHNEL, GOŁATA 2010; MAJEWSKA 2011; JANSSEN, SODERBERG, ZHOU 1999) and when dealing with geodetic network adjustment (KAMIŃSKI, NOWEL 1992; WIŚNIEWSKI 2009; HUBER 1981). The application of chosen algorithms of robust estimation in modeling market value is presented in the papers (ADAMCZYK 2017; LIGAS 2010).

It is important to notice that the problem of applying passive methods of robust estimation as a tool for preparing data for real estate market analysis is not widely described in Polish literature. In connection with the above, the present paper was prepared to indicate their usefulness in eliminating, from an analyzed dataset, data which are anomalous in regard to other observations. In effect, a database without outlying transactions which are fraught with gross error is obtained 
and prepared for selecting attributes which may have the greatest influence on unit price on the analyzed market.

\section{Chosen algorithms of robust estimation}

According to Hawkins's definition, an outlier is "an observation that deviates so much from other observations as to arouse suspicion that it was generated by a different mechanism", i.e. it comes from a different distribution than the remaining data in the dataset (HAWKINS1980). In connection with the above, in order to maintain data integrity, such observations ought to be pointed out and next, their influence on the analyzed data limited or eliminated.

Real estate market analysis is preceded by collecting a dataset of transactions which were carried out in the examined time. These data are described by independent variables which may have a significant influence on their unit price, which is the dependent variable. When entering information, mistakes caused by the human factor, e.g. literary error or the subjective opinion of the appraiser regarding the qualitative features of a property, may occur. These problems may be eliminated by using robust estimation.

The search for methods resistant to gross errors has made it possible for two groups of methods to be singled out in scientific literature, conventionally referred to as passive or active (KAMIŃSKI 2003).

Passive methods, which are the subject of this article, contain methods which are based on statistical tests, which allow, after adjustment with the least squares method, to select observations which may be fraught with gross error. These methods are: data snooping proposed by Baarda, and Pope's method.

Active methods, as opposed to passive ones, make it possible to eliminate the influence of gross errors in the process of adjusting measurement results. Generalizing, this group consists of methods which are resistant to gross errors because they do not contain temporary phases in the form of statistical tests (KAMIŃSKI 2003).

The detection of outliers is preceded by building a model of multiple regression based on a collected database of transactions, explanatory variables (property features) and the forecasted variable (unit price). The model can be presented by using a matrix notation in the following formula (BARAŃSKA 2007):

where:

$$
[C]=[X] \cdot[a]+[\delta]
$$

$$
\begin{aligned}
& {[C]=\left[\begin{array}{c}
c_{1} \\
c_{2} \\
\vdots \\
c_{n}
\end{array}\right] \text { - vector of forecasted variable (unit price), }} \\
& {[X]=\left[\begin{array}{cccc}
1 & x_{11} & \cdots & x_{1 m} \\
1 & x_{21} & \cdots & x_{2 m} \\
\vdots & \vdots & \ddots & \vdots \\
1 & x_{n 1} & \cdots & x_{n m}
\end{array}\right] \text { - matrix which contains values of explanatory variables (property features), }} \\
& {[a]=\left[\begin{array}{c}
a_{0} \\
a_{1} \\
\vdots \\
a_{m}
\end{array}\right] \text { - vector of coefficients of multiple regression, }} \\
& {[\delta]=\left[\begin{array}{c}
\delta_{1} \\
\delta_{2} \\
\vdots \\
\delta_{n}
\end{array}\right] \text { - vector of model random deviations. }}
\end{aligned}
$$

The estimator of the vector of coefficients $\hat{a}$ is determined according to the least squares method, and thus by maintaining the condition (2):

$$
\sum_{i=1}^{n}\left(c_{i}-w_{i}\right)^{2}=\delta^{T} \delta=\min
$$

where:

$c_{i}$ - observed price for $i^{\text {th }}$ property in the collected database, 
$w_{i}$ - model value for $i^{\text {th }}$ property,

$\delta=C-W$ - vector of random deviations (differences between observed price $C$ and model value $W$ ).

The solving of Equation (1) provides us with:

- the unencumbered estimator of the vector of unknowns:

$$
\hat{a}=\left(X^{T} X\right)^{-1} \cdot X^{T} C
$$

- the unencumbered estimator of residual variance which describes the inaccuracy of the estimation of model parameters:

$$
\hat{\sigma}_{0}^{2}=\frac{C^{T} C-\hat{a}^{T} X^{T} C}{n-(m+1)}
$$

- the covariance matrix of the vector of unknowns (model parameters):

$$
\operatorname{Cov}(\hat{a})=\hat{\sigma}_{0}^{2} \cdot\left(X^{T} X\right)^{-1}
$$

- the covariance matrix of model values:

$$
\operatorname{Cov}(W)=\hat{\sigma}_{0}^{2} \cdot X\left(X^{T} X\right)^{-1} X^{T}
$$

Verification of the relevance of the influence of every explanatory variable on the forecasted variable is conducted by statistical testing of the model parameters standing alongside individual variables. Hypotheses: zero $H_{0}$ and alternative $H_{1}$ take the following forms (BARAŃSKA 2012):

$$
\begin{aligned}
& H_{0}: a_{i}=0 \\
& H_{1}: a_{i} \neq 0
\end{aligned}
$$

The test function verifying the zero hypothesis on the irrelevent influence of the independent variable on the dependent variable comes from the $t$-Student distribution and is calculated as follows:

$$
T=\frac{\hat{a}_{i}}{\sigma\left(\hat{a}_{i}\right)}
$$

where:

$\hat{a}_{i}$ - estimator of model parameter $a_{i}$ $\sigma\left(\hat{a}_{i}\right)$ - standard deviation of $\hat{a}_{i}$ estimator.

\subsection{Baarda's method}

In the case of Baarda's method, it is assumed that observation corrections $v(v=-\delta)$ are random variables of normal distribution and the value of standard deviation $\sigma_{0}$ is known (BAARDA 1968). After solving of the set of equations (1), according to Formulas (2)-(6), the global test of the model is carried out, taking the following form:

$$
B=\frac{V^{T} V}{\sigma_{0}^{2}}=\frac{f \cdot \widehat{\sigma}_{0}^{2}}{\sigma_{0}^{2}} \sim \chi^{2}(f)
$$

where:

$f=n-(m+1)-$ number of degrees of freedom in chi-square $\chi^{2}$ distribution $(n-$ number of properties, $m$ number of attributes describing the property).

The zero hypothesis assumes that there are no gross errors in the observations. If for the assumed level of significance $a$, test statistics $B$ exceed the critical value, i.e.:

$$
B>\chi_{\alpha}^{2}(f)
$$

there are no reasons to accept the zero hypothesis and it is rejected.

The alternative hypothesis states that there is at least one gross error in an observation set. The search for outliers is done by testing individual observations, according to the equation:

$$
u_{i}=\frac{v_{i}}{\sigma_{v_{i}}}
$$

where: 
$v_{i}$-adjustment correction for $i^{\text {th }}$ observation,

$\sigma_{v i}$ average error of correction, calculated as:

$$
\begin{gathered}
\sigma_{v_{i}}=\sigma_{0} \sqrt{\left\{Q_{v}\right\}_{i i}} \\
Q_{v}=I-X\left(X^{T} X\right)^{-1} X^{T}
\end{gathered}
$$

where:

I - unit matrix,

$Q_{v}$ - co-factor matrix of correction vector,

$\left\{Q_{v}\right\}_{i i}$ - diagonal element of co-factor matrix of correction vector corresponding to the $i^{\text {th }}$ observation.

The zero hypothesis $H_{0}$ - for the test of the correction standardized for the given observation takes the

$$
H_{0}: \mathrm{E}\left(v_{\mathrm{i}}\right)=0
$$

if:

$$
\left|u_{i}\right| \leq u_{\alpha / 2}
$$

where:

$u_{a / 2}$ - the critical value of the test established from distribution $N(0 ; 1)$ for relevance level $a$ which corresponds to quantile $u(1-a / 2)$,

then there are no reasons to reject $H_{0}$.

In the case of not fulfilling the condition (16), the zero hypothesis $H_{0}$ is rejected and it is assumed that the observation is suspected of a so-called gross error.

If several observations do not fulfill (16), the observations must be deleted and next, the global test repeated (10). Eliminating outliers is done until $B \leq \chi_{\alpha}^{2}(f)$.

\subsection{Pope's method}

In this method, it is claimed that standard deviation $\sigma_{0}$ is unknown, which causes the global test not to be conducted as it had in Baarda's method. After the estimation of model parameters (1), according to Formulas (2)-(6) and after the verification of their influence on the forecasted variable (7)-(9), the method is based on a single observation test, where the test statistics takes the form of:

$$
P_{i}=\frac{v_{i}}{\sigma_{v_{i}}}=\frac{v_{i}}{\widehat{\sigma}_{0} \sqrt{\left\{Q_{v}\right\}_{i i}}} \sim \tau(f)
$$

where:

$v_{i}$ - adjustment correction for $i^{\text {th }}$ observation,

$\sigma_{v i}$ - average error of correction, calculated according to Equations (13) and (14), and $\sigma_{0} \approx \hat{\sigma}_{0}$,

$\tau(f)$ - $\tau$ distribution with $f$ degrees of freedom. There is a relationship between $t$-Student distribution and $\tau$-distribution, provided by the author of the method - Pope, caused by the fact that $\tau$ distribution is not in common use. This relationship between $t$-Student and $\tau$ distribution allows for using the $t$ Student chart according to the equation below:

$$
\tau_{(f)}=\frac{\sqrt{f} t_{(f-1)}}{\sqrt{f-1+t_{(f-1)}^{2}}}
$$

The same zero hypothesis (15) as in Baarda's method, is used for local tests concerning individual observations in the analyzed data set.

There are no reasons to reject the zero hypothesis if:

$$
\left|P_{i}\right| \leq \tau_{\alpha / 2}(f)
$$

After finding one or more observations suspected of gross errors, further actions involve deleting observations which do not fulfil Relationship (19) and the repeated adjustment of the set of equations, testing the significance of model parameter estimators $\hat{a}_{i}$, as well as conducting the test of an individual observation using Statistic (17). 


\section{Application of robust estimation for local real estate market analysis}

The considered database contained information about 204 sale transactions of flats with ownership titles, situated in the Kraków district of Krowodrza. Transactions took place from August to December, 2015 (an excerpt of the database is found in Table 1). Every property was described by quantitative features, which did not demand scaling (i.e. transaction date, floor area, number of rooms, flat location in building (floor), number of stories in the building, usable floor area and unit price) and qualitative features, for which a scale of 1 to 5 was assumed, with 1 meaning the lowest value and 5 signifying the highest (i.e. the surroundings, building condition, access to transportation, access to public places, availability of parking). The transaction date refers to the number of months from the date of first transaction in the analyzed database. All features, aside from the unit price, are explanatory variables, while unit price is the dependent variable. The correlation matrix between the analyzed features has been presented in Table 2 .

Table 1

Database of transaction properties (extract)

\begin{tabular}{|c|c|c|c|c|c|c|c|c|c|c|c|c|}
\hline 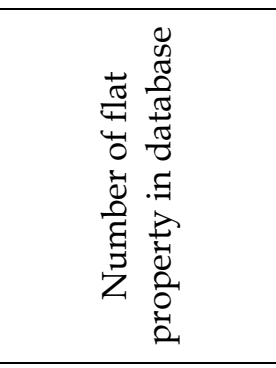 & 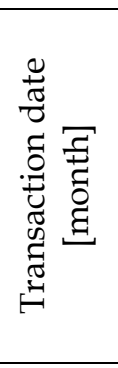 & 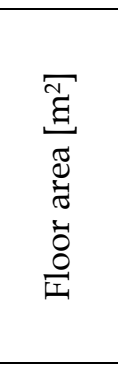 & 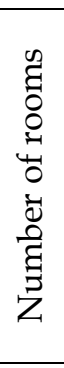 & 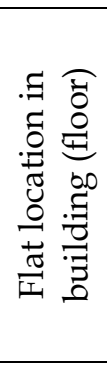 & 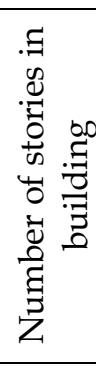 & 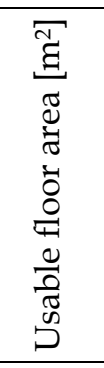 & 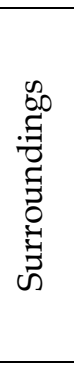 & 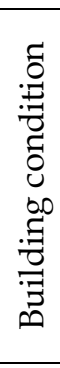 & 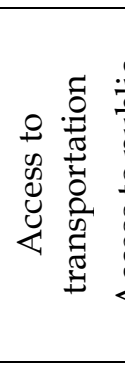 & 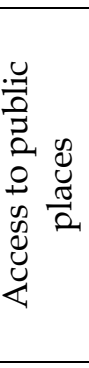 & 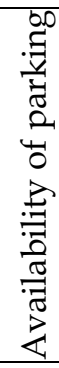 & 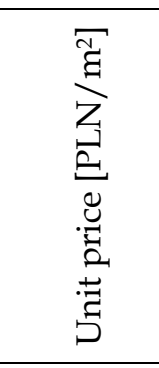 \\
\hline 1 & 1 & 49.29 & 3 & 5 & 4 & 3.00 & 5 & 5 & 4 & 5 & 2 & 6492.19 \\
\hline 2 & 1 & 38.00 & 3 & 5 & 3 & 4.01 & 3 & 5 & 3 & 3 & 4 & 5789.47 \\
\hline 3 & 1 & 30.00 & 2 & 8 & 11 & 0.00 & 4 & 3 & 4 & 4 & 4 & 6833.33 \\
\hline 4 & 1 & 26.03 & 1 & 2 & 4 & 0.00 & 4 & 4 & 4 & 4 & 4 & 6146.75 \\
\hline$\vdots$ & $\vdots$ & $\vdots$ & $\vdots$ & $\vdots$ & $\vdots$ & $\vdots$ & $\vdots$ & $\vdots$ & $\vdots$ & $\vdots$ & $\vdots$ & $\vdots$ \\
\hline 202 & 5 & 32.32 & 2 & 3 & 3 & 0.00 & 3 & 4 & 3 & 3 & 3 & 4795.79 \\
\hline 203 & 5 & 37.10 & 3 & 4 & 5 & 0.00 & 5 & 4 & 3 & 3 & 2 & 5256.06 \\
\hline 204 & 5 & 37.28 & 3 & 5 & 4 & 0.00 & 5 & 3 & 3 & 5 & 2 & 6410.94 \\
\hline Max. & 5 & 105.00 & 5 & 14 & 16 & 15.20 & 5 & 5 & 5 & 5 & 5 & 11228.81 \\
\hline Min. & 1 & 14.77 & 1 & 1 & 2 & 0.00 & 1 & 2 & 1 & 1 & 1 & 3373.69 \\
\hline Mean & 3 & 46.03 & 3 & 4 & 6 & 1.70 & 4 & 4 & 4 & 4 & 3 & 6403.52 \\
\hline tand. deviatio & 1 & 16.51 & 1 & 3 & 3 & 3.01 & 1 & 1 & 1 & 1 & 1 & 1364.83 \\
\hline
\end{tabular}

Source: Own study.

Table 2

Matrix of variable correlations creating the multiple regression model

\begin{tabular}{|c|c|c|c|c|c|c|c|c|c|c|c|c|}
\hline & 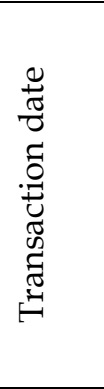 & $\begin{array}{l}\tilde{J} \\
\tilde{J} \\
\tilde{0} \\
\stackrel{0}{I} \\
\text { I. }\end{array}$ & 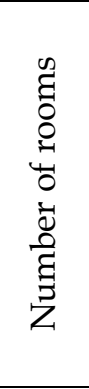 & 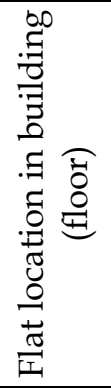 & 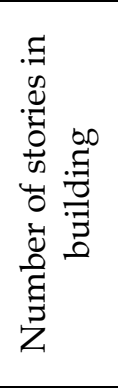 & 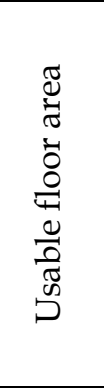 & 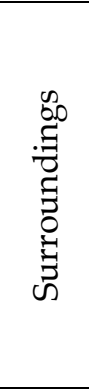 & 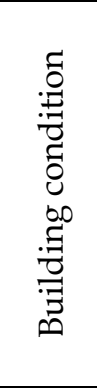 & 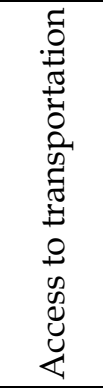 & $\begin{array}{l}0 \\
0 \\
\frac{0}{0} \\
2 \\
: 0 \\
0 \\
0 \\
0 \\
0 \\
0 \\
0 \\
0 \\
0 \\
0 \\
0\end{array}$ & 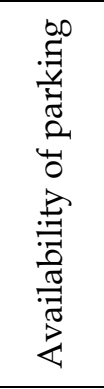 & 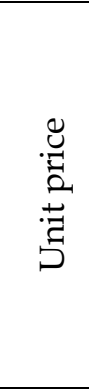 \\
\hline $\begin{array}{c}\text { Transaction } \\
\text { date }\end{array}$ & 1.00 & 0.02 & 0.02 & -0.11 & -0.03 & -0.14 & 0.12 & -0.02 & -0.05 & 0.01 & -0.12 & -0.17 \\
\hline
\end{tabular}




\begin{tabular}{cccccccccccccc}
\hline Floor area & 0.02 & 1.00 & 0.71 & 0.13 & 0.02 & 0.29 & -0.13 & 0.06 & 0.10 & 0.10 & -0.14 & -0.18 \\
\hline $\begin{array}{c}\text { Number } \\
\text { of rooms }\end{array}$ & 0.02 & 0.71 & 1.00 & 0.17 & 0.14 & 0.11 & -0.12 & 0.10 & 0.00 & -0.04 & -0.03 & -0.23 \\
\hline $\begin{array}{c}\text { Flat location } \\
\text { in building } \\
\text { (floor) }\end{array}$ & -0.11 & 0.13 & 0.17 & 1.00 & 0.57 & -0.03 & 0.06 & 0.14 & 0.14 & -0.08 & 0.03 & 0.05 \\
\hline $\begin{array}{c}\text { Number } \\
\text { of stories in } \\
\text { building }\end{array}$ & -0.03 & 0.02 & 0.14 & 0.57 & 1.00 & -0.07 & 0.03 & 0.12 & 0.15 & -0.10 & 0.12 & 0.04 \\
\hline
\end{tabular}

Table 2 cd.

Matrix of variable correlations creating the multiple regression model (continued)

\begin{tabular}{|c|c|c|c|c|c|c|c|c|c|c|c|c|}
\hline & 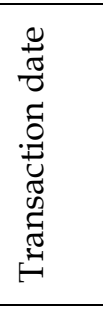 & 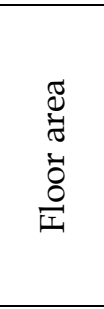 & 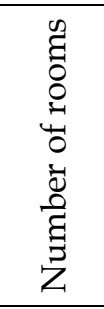 & 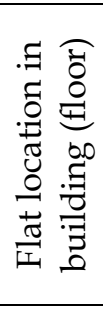 & 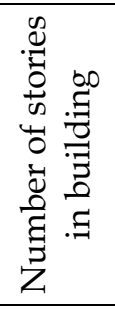 & 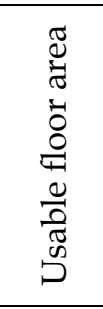 & $\begin{array}{l}\infty \\
\infty \\
: \\
0 \\
\vdots \\
0 \\
0 \\
\vdots \\
0\end{array}$ & 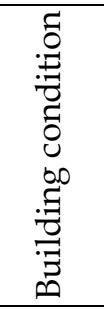 & 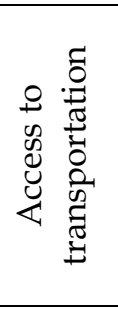 & 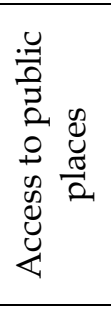 & 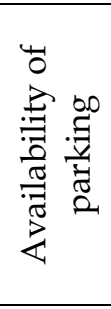 & 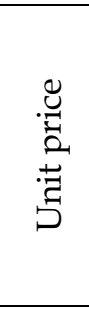 \\
\hline $\begin{array}{c}\text { Usable floor } \\
\text { area }\end{array}$ & -0.14 & 0.29 & 0.11 & -0.03 & -0.07 & 1.00 & 0.04 & -0.16 & 0.20 & 0.14 & -0.09 & -0.08 \\
\hline Surroundings & 0.12 & -0.13 & -0.12 & 0.06 & 0.03 & 0.04 & 1.00 & -0.36 & 0.59 & 0.61 & -0.68 & 0.23 \\
\hline $\begin{array}{l}\text { Building } \\
\text { condition }\end{array}$ & -0.02 & 0.06 & 0.10 & 0.14 & 0.12 & -0.16 & -0.36 & 1.00 & -0.41 & -0.39 & 0.32 & -0.16 \\
\hline $\begin{array}{c}\text { Access to } \\
\text { transportation }\end{array}$ & -0.05 & 0.10 & 0.00 & 0.14 & 0.15 & 0.20 & 0.59 & -0.41 & 1.00 & 0.62 & -0.52 & 0.27 \\
\hline $\begin{array}{c}\text { Access to } \\
\text { public places }\end{array}$ & 0.01 & 0.10 & -0.04 & -0.08 & -0.10 & 0.14 & 0.61 & -0.39 & 0.62 & 1.00 & -0.69 & 0.31 \\
\hline $\begin{array}{l}\text { Availability of } \\
\text { parking }\end{array}$ & -0.12 & -0.14 & -0.03 & 0.03 & 0.12 & -0.09 & -0.68 & 0.32 & -0.52 & -0.69 & 1.00 & -0.24 \\
\hline Unit price & -0.17 & -0.18 & -0.23 & 0.05 & 0.04 & -0.08 & 0.23 & -0.16 & 0.27 & 0.31 & -0.24 & 1.00 \\
\hline
\end{tabular}

Source: Own study.

\subsection{Baarda's method}

According to the assumptions, an a priori value of standard deviation $\sigma_{0}$ equal to $785.51 \mathrm{PLN} / \mathrm{m}^{2}$ was assumed for calculations. This value was $10 \%$ of the difference between the maximum $(11,228.81$ $\left.\mathrm{PLN} / \mathrm{m}^{2}\right)$ and minimum price $\left(3,373.69 \mathrm{PLN} / \mathrm{m}^{2}\right)$ in the collected database. This criterion was used because the value of 0.10 is assumed as the maximal probability of making a so-called type- 1 error in statistical tests.

The process of searching for outliers began with the determination of equation coefficients (1) by using the least squares method (2)-(3), and then verifying their statistical significance at the level of $a=$ 0.05 (7)-(9). Then, the estimator of residual variance $\hat{\sigma}_{0}^{2}(4)$ as well as test statistics $B(10)$ were indicated in a global test. The value of test statistics, at the level of significance $a=0.05$, indicated the necessity of rejecting the zero hypothesis $H_{0}$, which means that there were outlying transactions in the analyzed dataset. Next, a test for every correction was carried out, at the level of significance $a=0.05$, according 
to Formulas (12)-(16). Two iterations were done, each of them preceded by a global test (10), eliminating 41 observations considered to be outlying in terms of model prices in relation to observed prices in the gathered database on real estate.

The results of the carried out calculations for each iteration, accounting for significant variables of the model, are contained in Table 3.

Table 3

The results of Baarda's method for the analyzed real estate market

\begin{tabular}{c|c|c|c|c|c|c|c|c}
\hline $\begin{array}{c}\text { No. of } \\
\text { obs. }\end{array}$ & $\begin{array}{c}\hat{\sigma}_{0} \\
{[\mathrm{PLN} /} \\
\left.\mathrm{m}^{2}\right]\end{array}$ & $B$ & $\chi^{2}(f)$ & Conclusion & $\begin{array}{c}\text { No. of } \\
\text { outliers }\end{array}$ & $\begin{array}{c}C_{\text {mean }} \\
{[\text { PLN/ }} \\
\left.\mathrm{m}^{2}\right]\end{array}$ & $\begin{array}{c}\text { Variability } \\
\text { coefficient } \\
V=\frac{\hat{\sigma}_{0}}{c s ́}\end{array}$ & $\begin{array}{c}\text { Relevant } \\
\text { model } \\
\text { variables }\end{array}$ \\
\hline 164 & 1241.61 & 479.183 & $\begin{array}{c}\chi^{2}(199)= \\
=232.912 \\
\text { there is an } \\
\text { outlier } \\
\text { observation in } \\
\text { the database }\end{array}$ & 41 & 6403.52 & 0.19 & $\begin{array}{c}\text { trans. } \\
\text { date, no. } \\
\text { of rooms, } \\
\text { usable } \\
\text { floor area, } \\
\text { access } \\
\text { to public } \\
\text { places }\end{array}$ \\
\hline 730.22 & 136.538 & $\begin{array}{c}\chi^{2}(158)= \\
=188.332\end{array}$ & $\begin{array}{c}B<\chi^{2}(f) \\
\text { there is no } \\
\text { outlier } \\
\text { observation in } \\
\text { the database }\end{array}$ & 0 & 6222.15 & 0.12 & $\begin{array}{c}\text { trans. } \\
\text { date, } \\
\text { usable } \\
\text { floor area, } \\
\text { access to } \\
\text { public } \\
\text { places }\end{array}$ \\
\hline
\end{tabular}

Source: Own study.

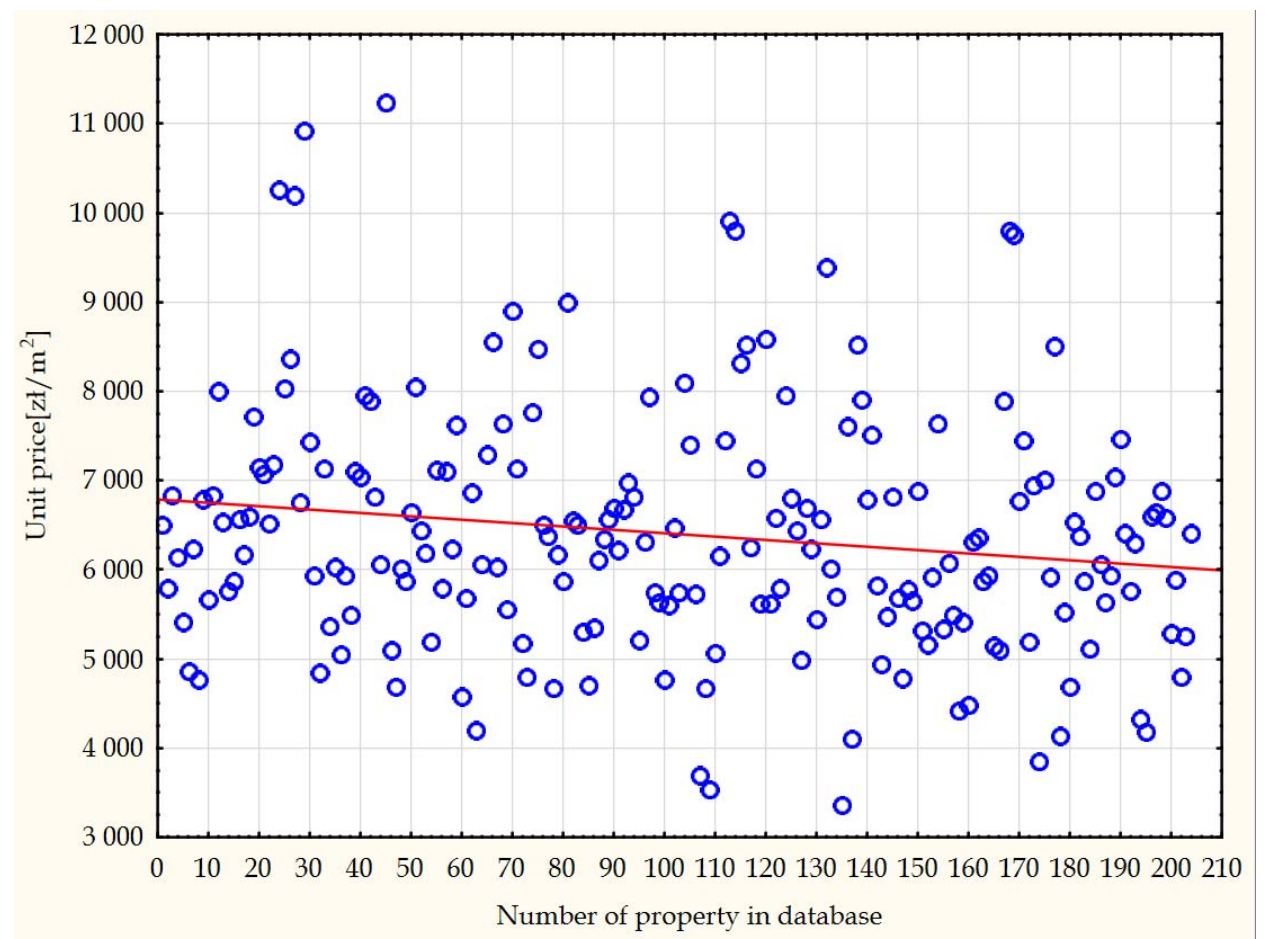

Fig. 1. Dispersion graph of unit prices before eliminating outlying observations. Source: Own study.

Variability coefficient $V$ informs us which part of the average value of the analyzed dependent variable of the model the standard deviation $\widehat{\sigma}_{0}$ comprises (BARAŃSKA 2012). After eliminating 41 observations, the variability coefficient changed from 0.19 to 0.12 , which signifies the growth of market data coherence in terms of the value of the dependent variable. Below are graphs which show 
the unit prices on the analyzed market before removing outlying observations (Fig. 1) as well as after eliminating them (Fig. 2).

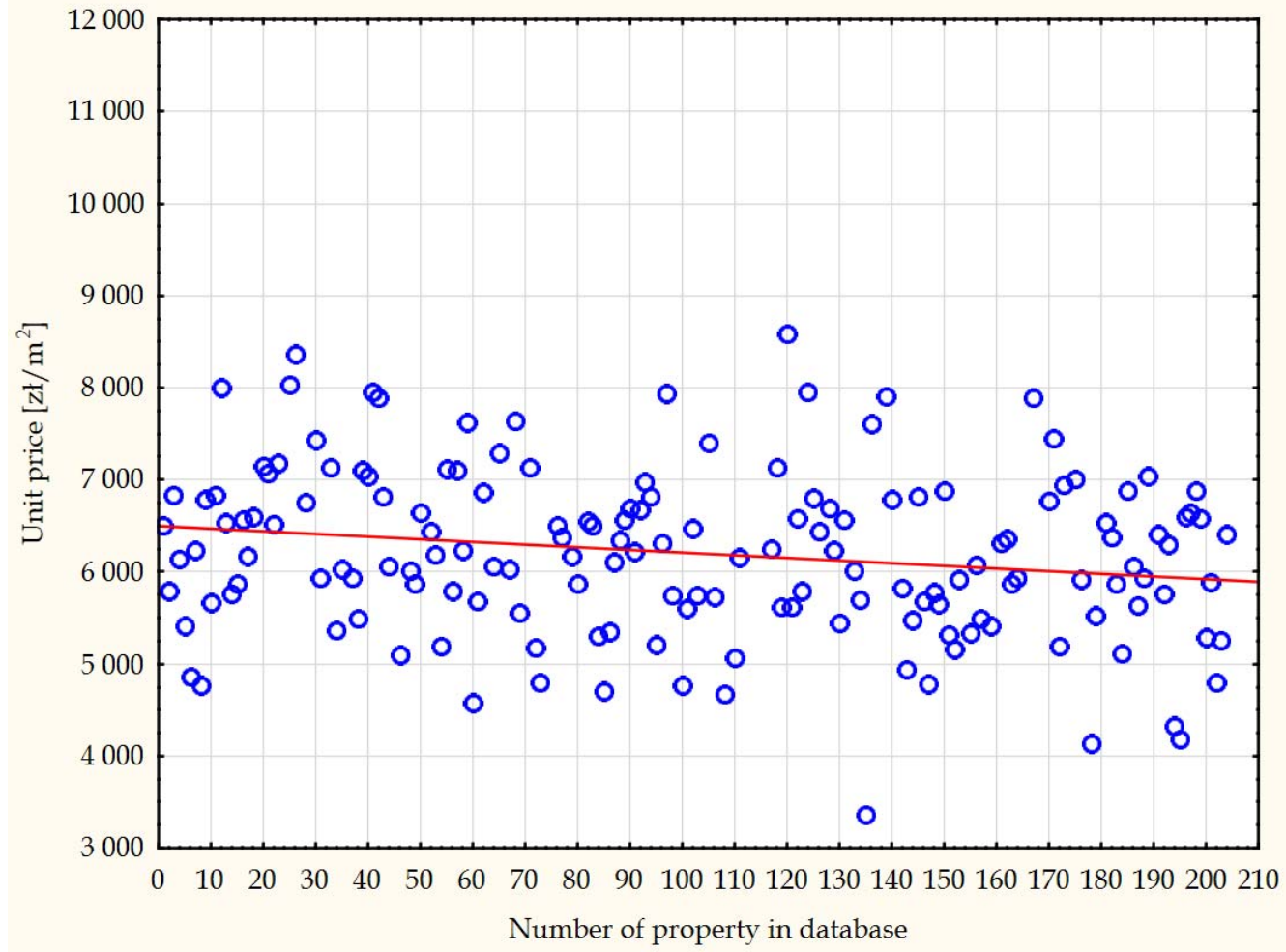

Fig. 2. Dispersion graph of unit prices after eliminating outlying observations by Baarda's method. Source: Own study.

It can be noticed that, after eliminating observations determined to be outlying from their model values, the dispersion of unit prices in the database dwindled significantly, with prices ranging from 3,300 to $8,800 \mathrm{PLN} / \mathrm{m}^{2}$.

\subsection{Pope's method}

The search for observations which varied from the model matched to them (1) was started by determining model parameters, according to Formulas (2)-(6), and with verification of their significance for $a=0.05$ (7)-(9). The critical value of $\tau$ distribution was calculated using the $t$-Student distribution chart (18). Next, at the level of significance $a=0.05$, the hypothesis for standardized correction in the form of $\mathrm{E}\left(v_{\mathrm{i}}\right)=0$ was verified. If Condition (19) was not fulfilled, the observation was said to be outlying and eliminated from the dataset.

Table 4 contains the calculation results in individual iterations, accounting for the number of observations, estimators of standard deviations (mean error of estimation) $\hat{\sigma}_{0}$ of individual models, the number of the degrees of freedom $f$, the critical value in the $\tau$ distribution, the number of outliers, the average unit price in the database, the coefficient of variation $V$ and the relevant variables of the model.

Table 4

Results of Pope's method for analyzed real estate market

\begin{tabular}{|c|c|c|c|c|c|c|c|c|}
\hline $\begin{array}{l}\text { No. of } \\
\text { iteration }\end{array}$ & $\begin{array}{c}\text { No. of } \\
\text { observation }\end{array}$ & $\begin{array}{c}\hat{\sigma}_{0} \\
{\left[\mathrm{PLN} / \mathrm{m}^{2}\right]}\end{array}$ & $\begin{array}{c}f \text { - no. of } \\
\text { freedom } \\
\text { degrees }\end{array}$ & $\tau(f)$ & $\begin{array}{l}\text { No. of } \\
\text { outliers }\end{array}$ & $\begin{array}{c}C_{s ́ r} \\
{\left[\mathrm{PLN} / \mathrm{m}^{2}\right]}\end{array}$ & $\begin{array}{c}\text { Variability } \\
\text { coefficient } V= \\
\frac{\widehat{\sigma}_{0}}{C s ́ r}\end{array}$ & $\begin{array}{l}\text { Relevant } \\
\text { variables } \\
\text { of model }\end{array}$ \\
\hline 1 & 204 & 1241.61 & 199 & 1.9578 & 11 & 6403.52 & 0.19 & $\begin{array}{c}\text { trans. } \\
\text { date, no. } \\
\text { of rooms, } \\
\text { usable }\end{array}$ \\
\hline
\end{tabular}


floor area, access to

public

places

Results of Pope's method for the analyzed real estate market (continued)

\begin{tabular}{|c|c|c|c|c|c|c|c|c|}
\hline $\begin{array}{l}\text { No. of } \\
\text { iteration }\end{array}$ & $\begin{array}{c}\text { No. of } \\
\text { observation }\end{array}$ & $\begin{array}{c}\hat{\sigma}_{0} \\
{\left[\mathrm{PLN} / \mathrm{m}^{2}\right]}\end{array}$ & $\begin{array}{l}f \text { - no. of } \\
\text { freedom } \\
\text { degrees }\end{array}$ & $\tau(f)$ & $\begin{array}{l}\text { No. of } \\
\text { outliers }\end{array}$ & $\begin{array}{c}C_{s i r} \\
{\left[\mathrm{PLN} / \mathrm{m}^{2}\right]}\end{array}$ & $\begin{array}{c}\text { Variability } \\
\text { coefficient } V= \\
\frac{\widehat{\sigma}_{0}}{C^{\prime} s} r \\
\end{array}$ & $\begin{array}{l}\text { Relevant } \\
\text { varaibles } \\
\text { of model }\end{array}$ \\
\hline 2 & 193 & 1045.10 & 190 & 1.9578 & 11 & 6289.23 & 0.17 & \multirow{2}{*}{$\begin{array}{c}\text { trans. } \\
\text { date, } \\
\text { access to } \\
\text { public } \\
\text { places }\end{array}$} \\
\hline 3 & 182 & 893.27 & 179 & 1.9576 & 7 & 6195.83 & 0.14 & \\
\hline 4 & 175 & 1172.18 & 171 & 1.9575 & 9 & 6134.06 & 0.19 & \multirow{5}{*}{$\begin{array}{c}\text { trans. } \\
\text { date, flat } \\
\text { location } \\
\text { in } \\
\text { building } \\
\text { access to } \\
\text { public } \\
\text { places }\end{array}$} \\
\hline 5 & 166 & 926.76 & 162 & 1.9574 & 5 & 6133.21 & 0.15 & \\
\hline 6 & 161 & 858.31 & 157 & 1.9573 & 3 & 6135.73 & 0.14 & \\
\hline 7 & 158 & 817.36 & 154 & 1.9572 & 1 & 6139.31 & 0.13 & \\
\hline 8 & 157 & 817.32 & 153 & 1.9572 & 0 & 6140.93 & 0.13 & \\
\hline
\end{tabular}

Source: Own study.

In order to eliminate data which were believed to be fraught with gross error, 8 iterations were carried out in Pope's method. It is important to note that only the model variables which were indicated as significant according to Test (7)-(9) were taken into consideration.

Below is a graph showing the unit prices on the analyzed market after eliminating a total of 47 outliers (Fig. 3). The unit prices of dwellings were in the range of 4,200 to $8,000 \mathrm{PLN} / \mathrm{m}^{2}$. The dispersion graph of unit prices prior to the application of Pope's method is found in Fig. 1.

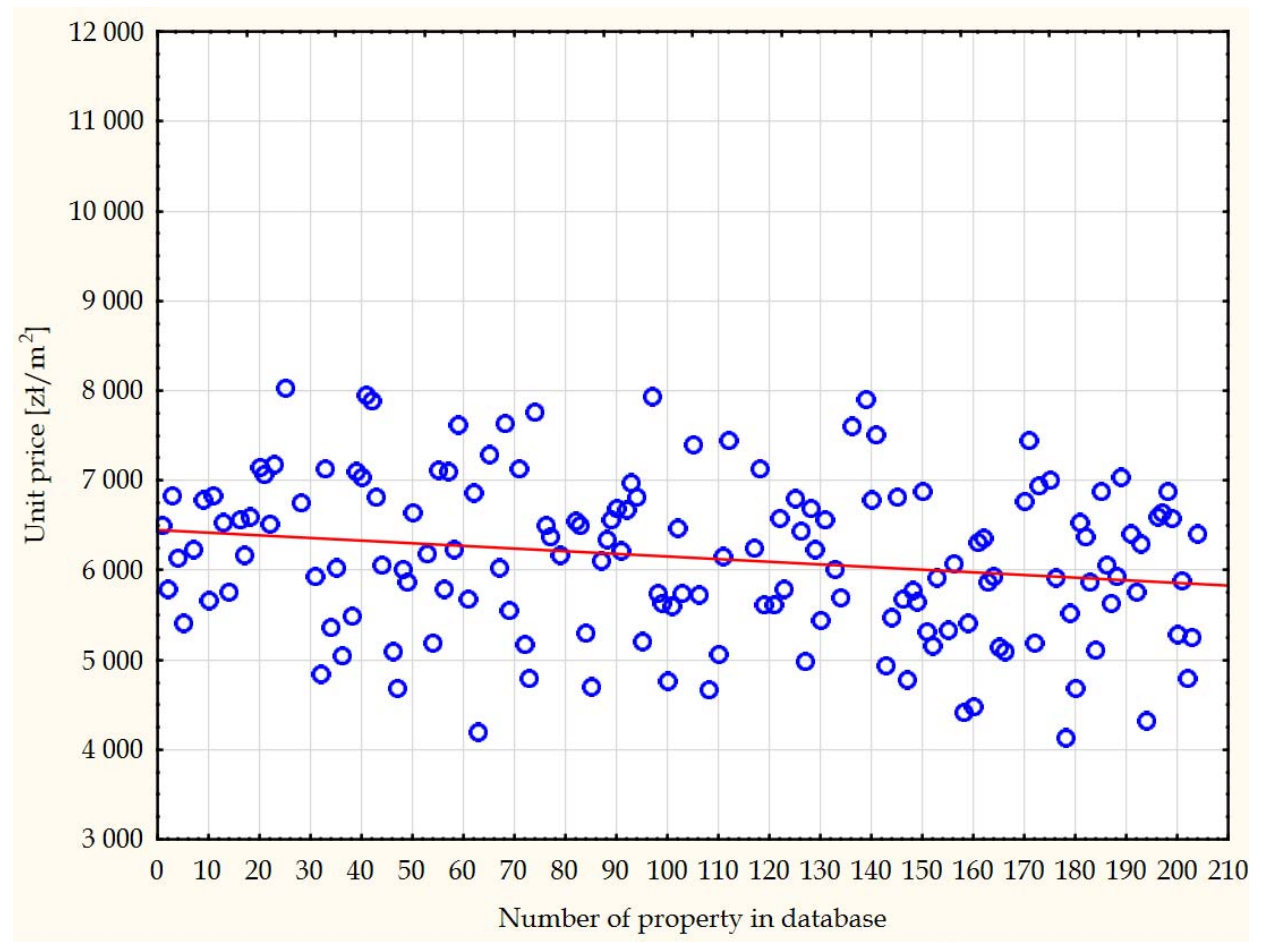

Fig.3. Dispersion graph of unit prices after eliminating atypical observations in Pope's method. Source: Own study. 


\section{Conclusions}

To sum up the conducted research on the application of robust estimation in real estate market analysis, both methods, i.e. Baarda's and Pope's, detected diverging observations (outliers) in the analyzed real estate database.

The value of standard deviation in Baarda's method is determined a priori. Accounting for the dispersion of prices of flats in the Krowodrza district, the value of standard deviation equal to 785.51 $\mathrm{PLN} / \mathrm{m}^{2}$ was assumed, with the average unit price for the entire collected database equal to $6,403.52$ $\mathrm{PLN} / \mathrm{m}^{2}$. This made it possible to identify 41 observations which were determined to be fraught with gross error. After eliminating them, the variability coefficient of the model was 0.12 . In relation to its initial value of 0.19 , when the number of observations in the dataset was 204, it can be said that the removal of untypical observations resulted in a significant increase in market data coherence in terms of the value of the dependent variable. This result substantiated the usefulness of this method in real estate market analysis.

The application of Pope's algorithm also detected outlying transactions on the analyzed property market. The difference in relation to Baarda's method was that the value of $\sigma_{0}$ was not assumed from the top, but resulted from the estimated model parameters (1), which meant that $\sigma_{0}$ was not dependent on the user. After eliminating outliers in the analyzed database, the variability coefficient underwent improvement and reached the level of 0.13 (with its initial value equal to 0.19), while standard deviation was $817.32 \mathrm{PLN} / \mathrm{m}^{2}$.

It is important to note that for the total elimination of atypical data, it was necessary to conduct 1 iteration in Baarda's method and 8 in Pope's method. Baarda's algorithm pointed to 41 outliers in relation to their model values, while Pope's algorithm detected 47 anomalous observations. Taking into consideration the initial number count of the database, the number of transactions treated as outliers is high (approx. 22\% of initial data). In connection with the above, the use of the considered methods of robust estimation should be more conservative, as there is a possibility of losing information that is representative of the analyzed dataset.

It is important that the same 29 real properties were selected as outlying observations in both considered methods. This group consisted mainly of flats, the unit price of which deviated greatly from the average unit price for the entire database. Pope's algorithm appeared to be more rigorous because of the number of eliminated transactions and price spread in the database. It cannot be claimed that the deleted data were unproductive - perhaps they contained other information than the majority of properties in Table 1 because they come from a different population or might have been sold at below or above their market value.

\section{References}

ADAMCZYK T., 2017, Application of the Huber and Hampel M-estimation in Real Estate Value Modeling, Geomatics and Environmental Engineering, Vol. 11, No. 1, pp. 15-23.

BAARDA W., 1968, A Resting Procedure for Use in Geodetic Networks, Publications on Geodesy, New Series, Netherlands Geodetic Commission, Vol. 2, No. 5.

BARAŃSKA A., 2007, Dwuetapowy model wyceny nieruchomości [Two-Stage Model for Estimating Real Estates], Journal of the Polish Real Estate Scientific Society, Olsztyn, Vol. 15, No. 3-4, pp. 187-195.

BARAŃSKA A., 2012, Statystyczna weryfikacja modeli wyceny nieruchomości [Statistical Verification of Real Estate Assessment Models], Journal of the Polish Real Estate Scientific Society, Olsztyn, Vol. 20, No. 1, pp. 29-39.

DeHNEL G., GoŁata E., 2010, Estymatory odporne w badaniu przedsiębiorczości [On Robust Estimators for a Polish Business Survey], Cracow Review of Economics and Management, Cracow, No. 10, pp. 107121.

HAWKINS D., 1980, Identification of Outliers, Chapman and Hall, Londyn.

HubER P.J., 1981, Robust Statistics, John Wiley and Sons, NowyJork.

JANSSEN C., SODERberG B., ZHOU J., 1999, Robust Estimation of Hedonic Models of Price and Income for Investment Property, Journal of Property Investment \& Finance, 19 ISSN: 1463 578X.

KAMIŃSKI W., NOWEL K., 1992, Analiza wybranych odpornych na btędy grube metod wyrównania obserwacji geodezyjnych [Analysis of Chosen Robust Methods of Geodetic Observation Adjustment], Geodesy and Cartography, No. 41, Vol. 3-4, pp. 173-195.

KAMIŃSKI W., 2003, Z odsiecza połowcom [With a Respite for Field People], Surveyor, No. 101, pp. 28-30. 
LigAs M., 2010, Metody statystyczne w wycenie nieruchomości [Statistical Methods in Real Estate Valuation], Journal of the Polish Real Estate Scientific Society, Olsztyn, Vol. 18, No. 1, pp. 49-63.

MAJEWSKA J., 2011, Analiza wptywu obserwacji ekstremalnych na pomiar ryzyka [Impact Analysis of Extreme Observations on the Calculation of Risk Measure], Economics Studies/University of Economics in Katowice, No. 96, pp. 69-82.

ORWAT A., 2006, Przykład zastosowania metody odpornej w modelowaniu finansowych szeregów czasowych [Sample Applications of Robust Estimation in Modelling Financial Time Series], Scientific Journal of Warsaw University of Life Sciences-SGGW, Warsaw, pp. 279-288.

PRÓSZYŃSKI W., KWAŚNIAK M., 2002, Niezawodność sieci geodezyjnych [Reliability of Geodetic Networks], Warsaw Polytechnic Publishing House.

TRZESIOK M., 2014, O jakości danych w kontekście obserwacji oddalonych w wielowymiarowej analizie regresji [On Selected Data Quality Issues in Multivariate Regression Analysis], Economic Studies. Journal of Economics and Management, Katowice, No. 191, pp. 75-88.

WIŚNIEWSKI Z., 2009, Rachunek wyrównawczy w geodezji (z przykładami) [Compensatory Calculation in Geodesy (with examples)], Warmia and Mazury Publishing House, Olsztyn. 